\title{
AKTIVITAS ANTIBAKTERI SEDIAAN KRIM KOMBINASI EKSTRAK KULIT BATANG MANGROVE (Avicennia marina) DAN MINYAK ATSIRI JERUK NIPIS (Citrus aurantifolia) TERHADAP PERTUMBUHAN Staphylococcus aureus ATCC 25923
}

\author{
Fiesta Eka Wahyuni ${ }^{* 1}$, Nikmah Nuur Rochmah ${ }^{* 2}$, Ikhwan Dwi Wahyu Nugroho ${ }^{3}$ \\ *1,2,3 Program Studi Sarjana Farmasi STIKES Al-Irsyad Al-Islamiyyah, Cilacap, Jawa Tengah, Indonesia \\ e-mail: ${ }^{1}$ fiestaekawahyuni@gmail.com, ${ }^{* 2}$ nikmah.nuur@gmail.com, ${ }^{3}$ ikhwandwiwahyunugroho@ yahoo.co.id
}

\begin{abstract}
ABSTRAK
Bakteri Staphylococcus aureus ATCC 25923 dapat menyebabkan beberapa infeksi seperti jerawat, bisul, luka, dan infeksi impetigo. Ekstrak Kulit Batang Mangrove (Avicennia marina) dan Minyak Atsiri Jeruk Nipis (Citrus aurantifolia) digunakan sebagai antibakteri karena dapat menekan pertumbuhan bakteri Staphylococcus aureus ATCC 25923. Penelitian dilakukan untuk mengetahui aktivitas antibakteri pada formula Krim Kombinasi Ekstrak Kulit Batang Mangrove dan Minyak Atsiri Jeruk Nipis. Metode penelitian eksperimental dengan variasi konsentrasi Ekstrak Kulit Batang Mangrove yaitu F1 (2,5\%), F2 (5\%), dan F3 (7,5\%). Hasil pengujian antibakteri sediaan krim terdapat aktivitas antibakteri hasil diameter zona hambat bakteri pada F1 (27mm), F2 (29mm) dan F3 (34mm) dan tergolong memiliki aktivitas daya hambat sangat kuat.
\end{abstract}

Kata Kunci: Jeruk Nipis (Citrus aurantifolia), Krim, Kulit Batang Mangrove (Avicennia Marina), Staphylococcus aureus ATCC.

\begin{abstract}
The bacterium Staphylococcus aureus ATCC 25923 can cause several infections such as acne, boils, wounds, and impetigo infections. Mangrove Bark Extract (Avicennia marina) and Lime (Citrus aurantifolia) Essential Oil were used as antibacterial because they could suppress the growth of Staphylococcus aureus ATCC 25923. The study was conducted to determine the antibacterial activity of the Combination Cream of Mangrove Bark Extract and Lime Essential Oil. Experimental research method with variations in the concentration of Mangrove Bark Extract, namely F1 (2.5\%), F2 (5\%), and F3 (7.5 $\%)$. The results of antibacterial testing of cream preparations showed antibacterial activity as a result of the diameter of the bacterial inhibition zone at F1 (27 mm), F2 (29mm) and F3 (34mm) and classified as having very strong inhibitory activity.
\end{abstract}

Keywords: Lime (Citrus aurantifolia), Cream, Mangrove Bark (Avicennia marina), Staphylococcus aureus ATCC 25923.

\section{PENDAHULUAN}

Penyakit bakteri akibat infeksi adalah masalah serius dalam kesehatan. Bakteri gram positif dan gram negatif serta mikroorganisme lainnya dapat menyebabkan infeksi pada manusia. bakteri yang dapat menyebabkan penyakit dan infeksi termasuk Staphylococcus aureus ATCC 25923. Staphylococcus aureus ATCC 25923 Ini adalah salah satu patogen manusia yang paling penting. Bakteri Staphylococcus aureus ATCC 25923 dapat menyebabkan beberapa infeksi seperti jerawat, bisul, luka, dan infeksi impetigo. Infeksi yang disebabkan oleh Staphylococcus aureus ATCC25923 dapat langsung atau tidak langsung. Infeksi Staphylococcus aureus ATCC 25923 juga dapat disebabkan oleh kontaminasi langsung pada luka. Bakteri ini disebut bakteri purulen karena menghasilkan nanah [1]. 
Tumbuhan Mangrove merupakan tumbuhan yang dapat digunakan sebagai antibakteri, tumbuhan ini hidup di daerah pesisir. Salah satu jenis mangrove yang banyak dijumpai yaitu mangrove Avicennia marina yang biasanya disebut sebagai Api-api. Dalam jurnal [2] mangrove Avicennia marina mengandung senyawa seperti alkaloid, flavonoid, fenol, terpenoid, steroid, dan saponin yang disebut metabolit sekunder. Menurut [3] pada Daun Avicennia marina mengandung senyawa alkaloid pada batang (steroid dan triterpenoid) dan akar (flavonoid). Kadar berbagai senyawa dalam mangrove berperan penting dalam menopang kehidupan, salah satunya yaitu sebagai antibakteri. Salah satu pemanfaatan tanaman mangrove Avicennia marina yaitu dengan cara mengambil ekstrak kulit batang mangrove (Avicennia marina) dengan cara maserasi. Berdasarkan penelitian yang dilakukan oleh Renaldi et al aktivitas ekstrak mangrove terhadap Staphylococcus aureus ATCC25923 dan Eschericiacoli, dapat disimpulkan bahwa bioaktivitas senyawa bioaktif Avicennia marina lebih tinggi dibandingkan dengan B. Gymnorrhiza terutama pada daun $(14,11 \mathrm{~mm})$, batang $(25,28 \mathrm{~mm})$ dan akar $(19,11 \mathrm{~mm})$ [3]. Jeruk nipis (Citrus aurantifolia) adalah salah satu jenis jeruk. Mengandung unsur senyawa yang bermanfaat. Misalnya minyak atsiri (limonene, linaline acetate, geranyl acetate, citrus lemon, actylaldehyde, nonyldehydr, canide, ferlandren, citral), $77,6 \%$ asam sitrat, lemak, mineral, asam amino (tryptophan, limonene), glikosida, asam sitrat. , Besi, belerang, vitamin B1. Jeruk Nipis (Citrus aurantifolia ) yang juga memiliki aktivitas antibakteri seperti yang dijelaskan pada penelitian Widiasningrum (2004) [4] menemukan bahwa minyak atsiri Jeruk Nipis (Citrus aurantifolia) mampu menghambat pertumbuhan bakteri Staphylococcus aureus pada konsentrasi 5\% sebesar $(5,4 \mathrm{~mm})$, konsentrasi $10 \%$ sebesar $(9,6 \mathrm{~mm})$, konsentrasi $15 \%$ sebesar $(14,3 \mathrm{~mm})$ dan konsentrasi $20 \%$ sebesar $(20,1 \mathrm{~mm})$. Bentuk sediaan topikal yang sekarang ini dikembangkan oleh industri farmasi dan kosmetik, serta beberapa lembaga penelitian yaitu sediaan krim. Selain itu, krim merupakan bentuk sediaan topikal dengan bentuk semi padat yang cocok untuk perawatan kulit seperti luka pada kulit, gatal-gatal, menghilangkan bekas luka atau luka. Lebih baik menggunakan krim karena menyebar secara merata dan mudah dibersihkan dan dicuci [5].

\section{METODE PENELITIAN}

Metode yang digunakan dalam penelitian ini adalah metode eksperimental. Dimana penelitian ini dilakukan di Laboratorium Teknologi Sediaan Farmasi dan Laboratorium Kimia STIKES Al-Irsyad Al Islamiyyah Cilacap pada bulan Maret 2021. Pengumpulan data dilakukan dengan cara ceklis dengan buku yang disiapkan untuk penelitian dan pelaksanaan penelitian dicatat dibuku logbook. Data yang digunakan adalah data hasil uji aktivitas antibakteri terhadap sediaan krim dan uji sifat fisik sediaan krim. Uji sifat fisik meliputi uji organoleptis, uji daya lekat, uji daya sebar, uji viskositas, uji $\mathrm{pH}$, serta uji tipe sediaan krim. Metode analisis yang digunakan yaitu metode deskriptif.

\subsection{Alat dan Bahan}

Alat

Alat yang digunakan pada penelitian ini yaitu Jas lab, Neraca analitik Ohauss (PioneerTM ${ }^{\circledR}$ ), Alat - alat gelas (Pyrex $\left.{ }^{\circledR}\right)$, Pisau, Oven (Memmert $\left.{ }^{\circledR}\right)$, Blender (Miyako ${ }^{\circledR}$ ), Ayakan, Bejana, Batang engaduk, Kain flanel, Kertas saring, Gelas ukur (Pyrex®), Corong buchner(Pyrex®), Penangas air, Desikator (Iwaki $\left.{ }^{\circledR}\right)$, Cawan porselen, Mortir, stampher, Sudip, Wadah krim,Viskometer, Autoklaf (GEA model YX-18LM), Iinkubator (Memmert®), Cawan petri, Jarum ose, Bunsen, Kompor listrik (Maspion®), Vorteks (VM-300), Tabung reaksi (Pyrex $\left.{ }^{\circledR}\right)$, Yellow tip (Onemed $\left.{ }^{\circledR}\right)$, Mikro pipet (Socorex), Sarung tangan (Sensi Gloves ${ }^{\circledR}$ ), Masker (Sensi Mask $\left.{ }^{\circledR}\right)$, pH meter (Neschgo $\left.{ }^{\circledR}\right)$, Objek glass, Ekstensometer, Anak timbangan. 


\section{Bahan}

Bahan yang digunakan adalah kulit batang mangrove (Avicennia marina), Minyak Atsiri Jeruk Nipis (Citrus aurantifolia), Cera Alba (Malam putih) (Bratacoß), Asam stearat(Bratacoß), Vaselin Flavum (Vaselin kuning)(Brataco $\left.{ }^{\circledR}\right)$, Trietanolamin (TEA)(Brataco®), Propilen glikol(Brataco®), Metil paraben (Nipagin)(Brataco®), Aquadest(Brataco®), Etanol 96\%(Brataco®), Krim Chloramphenicol,Kertas Cakram, Media NA(Nutrient Agar), Bakteri $S$. aureus, Natrium Clorida0,9\% ( $\mathrm{NaCl} 0,9 \%)$, Asam Sulfat $\left(\mathrm{H}_{2} \mathrm{SO}_{4}\right)($ Brataco®), Asam Asetat $\left(\mathrm{CH}_{3} \mathrm{COOH}\right)($ Brataco $\AA)$, Kloroform(Brataco $\left.{ }\right)$, Asam Klorida $(\mathrm{HCl})($ Brataco®), Reagen Dragendroff, Logam Magnesium(Logam Mg).

\subsection{Jalannya Penelitian}

\subsubsection{Determinasi Kulit Batang Mangrove (Avicennia marina)}

Tujuan dari uji determinasi yang dilakukan kali ini yaitu untuk membuktikan kebenaran bagian tanaman yang digunakan pada penelitian.

\subsubsection{Preparasi Sampel}

Sampel diambil dari salah satu wilayah di Kabupaten Cilacap, Jawa Tengah. Kulit batang mangrove (Avicennia marina) yang diambil yaitu berwarna coklat yang sudah tua dari bagian batang pohon atau bagian tangkai batang pohon.

Sampel minyak atsiri Jeruk Nipis (Citrus aurantifolia) yang digunakan dalam penelitian ini merupakan hasil minyak atsiri yang berasal PT. Darjeeling Sembrani Aroma.

\subsubsection{Pembuatan Ekstrak Kulit Batang Mangrove (Avicennia marina)}

Sampel diekstraksi dengan pelarut etanol 96\%. Sampel kulit batang mangrove (Avicennia marina) yang telah dibersihkan dan disortir ditimbang sebanyak $500 \mathrm{~g}$, dimasukan kedalam wadah maserasi, kemudian ditambahkan etanol 96\% dengan perbandingan (1:3, b/v) selama 2 X 24 jam pada suhu ruangan, dan dilakukan remaserasi sebanyak 1 kali. Kemudian hasil ekstrak diuapkan untuk menghilangkan pelarut etanol $96 \%$ dengan menggunakan waterbath dengan suhu $60^{\circ} \mathrm{C}$ sampai diperoleh ekstrak kental.

\subsubsection{Penetapan Kadar Air}

Sebanyak 1 g ekstrak kulit batang mangrove (Avicennia marina) diletakan pada kertas saring kemudian dikeringkan dengan oven pada suhu $105^{\circ} \mathrm{C}$ Selama 60 menit. Hasil pengeringan ditimbang dan dihitung berat kertas saring sebelum dan sesudah dikeringkan.

\subsubsection{Uji Bebas Etanol Ekstrak Kulit Batang Mangrove (Avicennia marina)}

Uji bebas etanol ekstrak etanol kulit batang mangrove (Avicennia marina), dilakukan dengan menggunakan metode esterifikasi etanol, dengan cara diambil $1 \mathrm{~g}$ ekstrak kulit batang mangrove (Avicennia marina) lalu dimasukkan kedalam tabung reaksi ditambahkan $1 \mathrm{~mL}$ asam asetat dan $1 \mathrm{~mL}$ asam sulfat pekat kemudian dihomogenkan dan dipanaskan diatas bunsen, atas tabung ditutup dengan kapas, ekstrak telah bebas etanol ditandai dengan tidak timbulnya bau ester yang menguap selama proses pemanasan [5].

\subsubsection{Skrining Fitokimia Ekstrak Kulit Batang Mangrove A. marina}

\section{a. Uji Alkaloid}

$5 \mathrm{ml}$ ekstrak kulit batang mangrove (Avicennia marina) ditambahkan dengan 2 $\mathrm{ml} \mathrm{HCl} \mathrm{kemudian} \mathrm{ditambahkan} \mathrm{Reagen} \mathrm{Dragendorff.} \mathrm{Ekstrak} \mathrm{yang} \mathrm{positif} \mathrm{mengandung}$ alkaloid akan menunjukkan warna orange atau merah pada presipitat [6].

b. Uji Flavonoid

Ekstrak kulit batang mangrove (Avicennia marina) sebanyak $1 \mathrm{mg}$ dimasukan ke dalam tabung reaksi, setelah itu ditambahkan logam $\mathrm{Mg}$ dan 4-5 tetes $\mathrm{HCl}$ pekat. Larutan berwarna merah atau jingga yang terbentuk menunjukan adanya flavonoid [6].

\section{c. Uji Steroid Dan Terpenoid}

Ekstrak kulit batang mangrove (Avicennia marina) dilarutkan dalam kloroform kemudian ditambahkan pereaksi $\mathrm{H}_{2} \mathrm{SO}_{4}$ secara pelan dan hati-hati,menunjukan hasil positif dengan adanya perubahan warna menjadi merah kecoklatan untuk steroid dan coklat ungu untuk triterpenoid [6]. 


\section{d. Uji Tanin}

$5 \mathrm{ml}$ Ekstrak kulit batang mangrove (Avicennia marina) dilarutkan dalam air dan direaksikan dengan $\mathrm{FeCl} 31 \%$ menunjukan hasil negatif dengan tidak adanya perubahan warna menjadi hijau hingga biru kehijauan [6].

e. Uji Saponin

Ekstrak kulit batang mangrove (Avicennia marina) dimasukan dalam tabung reaksi kemudian dikocok. uji saponin tidak menunjukkan hasil positif karena buih yang terbentuk setelah pengocokan tidak bertahan lama, hanya bertahan beberapa detik [7].

\section{f. Minyak atsiri}

Pengujian minyak atsiri dilakukan dengan cara menimbang sebanyak $0,5 \mathrm{~g}$ ekstrak dimasukkan dalam tabung reaksi, ditambah tetes pereaksi sudan III. Hasil menunjukkan reaksi positif jika larutan berwarna merah [8].

\subsubsection{Formulasi Sediaan Krim Kombinasi Ekstrak Kulit Batang Mangrove (Avicennia marina) Dan Minyak Atsiri Jeruk Nipis (Citrus aurantifolia)}

\section{a. Formulasi Krim}

Tabel I. Formulasi Krim Ekstrak Kulit Batang Mangrove (Avicennia marina) Kombiasi Minyak Atsiri Jeruk Nipis (Citrus aurantifolia)

\begin{tabular}{|c|c|c|c|c|c|}
\hline \multirow[b]{2}{*}{ Bahan } & & \multicolumn{4}{|c|}{ Formulasi } \\
\hline & & $\mathbf{0}$ & 1 & 2 & 3 \\
\hline Ekstrak (Avicennia marina) (\%) & & - & 2,5 & 5 & $\mathbf{7 , 5}$ \\
\hline $\begin{array}{l}\text { Minyak Atsiri Jeruk Nipis } \\
\text { aurantifolia) }(\%)\end{array}$ & (Citrus & - & 5 & 5 & 5 \\
\hline Cera Alba $(\mathrm{g})$ & & 1 & 1 & 1 & 1 \\
\hline Asam Stearat (g) & & 7,5 & 7,5 & 7,5 & 7,5 \\
\hline TEA $(\mathrm{g})$ & & 0,75 & 0,75 & 0,75 & 0,75 \\
\hline Vaselin Flavum (g) & & 4 & 4 & 4 & 4 \\
\hline Metil Paraben (g) & & 0,12 & 0,12 & 0,12 & 0,12 \\
\hline Propilen glikol (g) & & 4 & 4 & 4 & 4 \\
\hline Aqudes ad. $(\mathrm{ml})$ & & 50 & 50 & 50 & 50 \\
\hline
\end{tabular}

Keterangan : Pada Formulasi Krim Ekstrak Kulit Batang Mangrove(Avicennia marina) Kombiasi Minyak Atsiri Jeruk Nipis (Citrus aurantifolia) (F1,F2,F3 terdapat variasi konsenttrasi pada Krim Ekstrak Kulit Batang Mangrove (Avicennia marina) dan pada F 0 (Basis Krim).

\section{b. Pembuatan Sediaan Krim}

Formulasi sediaan krim dapat dilihat pada Tabel I. Pembuatan basis krim tipe $\mathrm{M} / \mathrm{A}$ dilakukan sesuai dengan komposisi formula yang tertera pada Tabel dengan cara dimasukan dalam masing-masing cawan porselin. fase minyak (cera alba, asam stearat, dan vaselin flavum) dileburkan di atas penangas air pada suhu $75^{\circ} \mathrm{C}$, ad apun fasa air (TEA dan propilen glikol) dileburkan pada suhu $75^{\circ} \mathrm{C}$. Fase air (campuran TEA dan propilen glikol) tersebut kemudian dimasukkan ke dalam lelehan cera alba, asam sterat, dan vaselin flavum, lalu diaduk hingga homogen dalam mortir hangat hingga terbentuk masa krim lalu tambahkan aquadest panas sebagai pelarut ke dalam mortir kemudian dihomogenkan. Selanjutnya campuran tersebut ditambahkan metil paraben sebagai pengawet. Setelah krim dingin kemudian tambahkan Ekstrak Kulit Batang mangrove (Avicennia marina) Kombiasi Minyak Atsiri Jeruk Nipis (Citrus aurantifolia) aduk hingga homogen, setelah homogen kemudian krim dimasukan ke dalam wadah. Selanjutnya dilakukan uji tipe krim dan uji fisik krim ekstrak kulit batang mangrove (Avicennia marina) Dan Minyak Atsiri Jeruk Nipis (Citrus aurantifolia). 


\subsubsection{Evaluasi Karateristik Fisik Krim}

\section{a. Uji Organoleptis}

Tujuan pengujian secara organoleptis adalah untuk mengetahui penampilan fisik sediaan Krim. Evaluasi organoleptis meliputi pengamatan secara visual perubahanperubahan bentuk, bau dan warna pada sediaan krim pada suhu kamar $\left(25^{\circ} \mathrm{C}\right)$.

\section{b. Uji Homogenitas Krim}

Krim diambil dari masing-masing formula secukupnya dan dioleskan pada plat kaca, diraba dan saat digosokkan massa krim harus menunjukkan susunan homogen yaitu tidak terasa adanya bahan padat pada kaca [9].

\section{c. Uji Daya Sebar}

Ditimbang 0,5 g krim diletakkan di tengah alat (kaca bulat), ka cabulat bagian atas ditimbang terlebih dahulu dan diletakkn diatas krim, biarkan selama 1 menit, diukur diameter krim yang menyebar (diambil panjang rata-rata diameter dari beberapa sisi), ditberi beban $50 \mathrm{~g}, 100, \mathrm{~g}, 150 \mathrm{~g}$, dan $200 \mathrm{~g}$. Sebagai beban tambahan secara bertahap, setiap penambahan beban didiamkan selama 1 menit dan dicatat diameter krim yang menyebar. Cara diatas diulangi sebanyak 3 kali tiap fomulanya [9].

\section{d. Uji pH}

Pengukuran $\mathrm{pH}$ sediaan dilakukan menggunakan indikator universal, indikator universal dicelupkan ke dalam sediaan krim. Setelah tercelup dengan sempurna, amati perubahan warna pada indikator universal tersebut dan sesuaikan dengan spektrum warna pada alat [5].

\section{e. Uji Daya Lekat}

Krim diambil sebanyak $0,25 \mathrm{~g}$ kemudian dioleskan pada sebuah plat kaca. Kedua plat ditempelkan sampai plat menyatu dan ditekan dengan beban seberat $1 \mathrm{~kg}$ selama 5 menit, setelah itu beban diambil. Waktu sampai kedua plat saling lepas dicatat, kemudian dilakukan pengulangan sebanyak 3 kali untuk masing-masing formula [9].

\section{f. Uji Viskositas}

Viskositas sediaan krim diukur menggunakan Viskometer Brookfield. Sediaan krim sebanyak $\pm 200 \mathrm{~g}$ dimasukkan ke dalam cup. Kemudian dipasang spindle ukuran 64 dan rotor dijalankan dengan kecepatan $10 \mathrm{rpm}$. Hasil viskositas dicatat setelah Viskometer menunjukan angka yang stabil [9].

\section{g. Uji Tipe Krim}

Untuk memastikan tipe krim yang dibuat sesuai dengan tipe krim yang diharapkan.

\subsubsection{Uji Aktivitas Antibakteri Sediaan Krim Ekstrak Kulit Batang Mangrove (Avicennia marina) Kombiasi Minyak Atsiri Jeruk Nipis (Citrus aurantifolia)}

\section{a. Penyiapan Alat Dan Sterilisasi}

Beker glass, gelas ukur, erlenmeyer dan karet pipet yang sudah dibungkus, disterilkan terlebih dahulu di dalam autoklaf pada suhu $121^{\circ} \mathrm{C}$ selama 15 menit, dan alat-alat seperti batang pengaduk, pinset, spatula, gelas arloji yang sudah dibungkus dimasukkan dalam oven pada suhu $160-170^{\circ} \mathrm{C}$ selama \pm 2 jam, jarum ose dan pinset dibakar dengan pembakaran diatas api bunsen [6]. 


\section{b. Pembuatan Media NA (Nutrient Agar)}

Sebanyak 7, $25 \mathrm{~g}$ nutrient agar disuspensikan dalam $250 \mathrm{~mL}$ aquades steril, kemudian dimasukan kedalam labu erlenmeyer dipanaskan menggunakan hotplate selama \pm 10 menit hingga larut. Kemudian disterilkan dengan autoklaf pada suhu $121^{\circ} \mathrm{C}$. Media yang sudah steril, dituangkan dalam kondisi hangat $\left(40^{\circ} \mathrm{C}-45^{\circ} \mathrm{C}\right) \mathrm{ke}$ dalam cawan petri. Media nutrien agar yang telah dituangkan ke dalam cawan petri dibiarkan hingga memadat.

\section{c. Pembuatan Suspensi Bakteri}

Hasil inokulasi Staphylococcus aureus ATCC 25923 dimasukan dalam tabung reaksi dengan kawat ose seteril yang berisi $2 \mathrm{ml} \mathrm{NaCl} 0,9 \%$ kemudian dihomogenkan dan dibandingkan dengan kekeruhan standar $M c$ Farland. Pembuatan standar Mc Farland laruran $\mathrm{H}_{2} \mathrm{SO}_{4} 1 \%$ sebanyak $9,95 \mathrm{~mL}$ dicampurkan dengan larutan $\mathrm{BaCl}_{2} \cdot 2 \mathrm{H}_{2} \mathrm{O} \quad 1,175 \%$ sebanyak $0,05 \mathrm{~mL}$ dalam erlenmeyer. Kemudian digojok sampai terbentuk larutan yang keruh. Kekeruhan ini dipakai sebagai standar kekeruhan suspensi bakteri uji.

d. Uji Aktivitas Antibakteri Sediaan Krim Ekstrak Kulit Batang Mangrove (Avicennia marina) Kombiasi Minyak Atsiri Jeruk Nipis (Citrus aurantifolia)

Pada penelitian ini menggunakan 3 kelompok yaitu sediaan krim ekstrak kulit batang mangrove (Avicennia marina) Kombiasi Minyak Atsiri Jeruk Nipis (Citrus aurantifolia)(F1, F2, F3), kontrol negatif berupa sediaan krim tanpa zat aktif, kemudian kontrol positif berupa krim antibiotik Kloramfenikol, metode uji antibakteri yang digunakan pada penelitian ini adalah difusi sumuran.

Pertama suspensi bakteri Staphylococcus aureus ATCC 25923 dicampurkan media Nutrient agar steril, lalu didiamkan hingga setengah mengeras. Selanjutnya, dibuat sumur (well) dengan menggunakan bor gabus pada media cawan petri dengan diameter $\pm 8 \mathrm{~mm}$. Satu cawan petri berisi 5 sumuran dengan jarak sumuran yang telah diatur, dimasukkan masing-masing formulasi sediaan krim Ekstrak Kulit Batang Mangrove (Avicennia marina) Kombiasi Minyak Atsiri Jeruk Nipis (Citrus aurantifolia), krim tanpa zat aktif untuk kontrol negatif, kontrol positif berupa sediaan krim kloramfenikol, pada masing-masing sumur yang telah diberi tanda. Kemudian dimasukkan cawan petri tersebut ke dalam inkubator dan ditunggu selama 24 jam pada suhu $37^{\circ} \mathrm{C}$. Akan nampak area bening di sekitar sumur yang bersih atau tanpa koloni bakteri, yang disebut zona hambat. Dihitung diameter zona hambat.

\subsection{Analisis Data}

Data yang diperoleh berupa hasil analisis pengaruh aktivitas sediaan Krim Ekstrak Kulit Batang Mangrove (Avicennia marina) Kombiasi Minyak Atsiri Jeruk Nipis (Citrus aurantifolia). Data dianalisis secara deskriptif kualitatif dengan menampilkan hasil uji.

\section{HASIL DAN PEMBAHASAN}

\subsection{Pengambilan Sampel}

Pada penelitian ini Kulit Batang Mangrove (Avicennia marina) dari salah satu wilayah di Kabupaten Cilacap tepatnya di tempat sekitar perairan Kampung Laut Cilacap, Jawa Tengah. Kulit Batang Mangrove (Avicennia marina) yang diambil yaitu dari bagian batang pohon segar yang sudah tua berwarna coklat kehijauan. Karena pada kulit batang mangrove yang masih segar dan sudah tua berwarna coklat kehijauan ini yang nantinya dapat dijadikan sebagai ekstrak kental. Sampel minyak atsiri Jeruk Nipis (Citrus aurantifolia) yang digunakan 
dalam penelitian ini merupakan hasil minyak atsiri yang berasal PT. Darjeeling Sembrani Aroma.

\subsection{Identifikasi Sampel Kulit Batang Mangrove (Avicennia marina) dan Minyak Atsiri Jeruk Nipis (Citrus aurantifolia)}

Pengujian determinasi tumbuhan merupakan tahap awal untuk menetapkan kebenaran bahan tumbuhan yang digunakan dalam penelitian. Pengujian determinasi tumbuhan Kulit Batang Mangrove (Avicennia marina) dilakukan di Laboratorium Biologi Universitas Muhamadiyyah Purwokerto (UMP). Pada identifikasi dan mutu bahan minyak atsiri Jeruk Nipis (Citrus aurantifolia) dilakukan dengan membandingkan data sampel pemeriksaan atau pengujian dengan menggunakan persyaratan standar, namun karena standar SNI untuk minyak atsiri Jeruk Nipis (Citrus aurantifolia) belum ditentukan, sehingga pada pengujian ini menggunakan referensi dari penelitian sebelumnya. Minyak atsiri Jeruk Nipis (Citrus aurantifolia) yang diperoleh dari PT. Darjeeling Sembrani Aroma, berdasarkan data dapat disimpulkan memenuhi persyaratan standar mutu minyak atsiri.

\subsection{Pembuatan Ekstrak Kulit Batang Mangrove (Avicennia marina)}

Ekstraksi dilakukan menggunakan metode maserasi dengan pelarut etanol 96\% dengan perbandingan (1:3, b/v) selama 2 x 24 jam dan remaserasi sebanyak 1 kali. Hasil ekstraksi maserasi dari sampel ekstrak kulit batang mangrove (Avicennia marina) sebanyak $500 \mathrm{~g}$ menghasilkan ekstrak kental yang berwarna hijau kehitaman sebesar 38,50 g, dengan nilai rendemen sebesar $7,7 \%$.

\subsection{Penetapan Kadar Air}

Tujuan dari penentuan kadar air adalah untuk mengetahui kualitas bahan yang digunakan untuk kadar air yang terkandung dalam sampel. Karena air merupakan tempat berkembang biak bagi pertumbuhan dan perkembangan jamur. Berdasarkan batasan persyaratan kadar air standar Simplicia dalam kisaran kadar air ekstrak kering < 5\%, ekstrak kental 5-10\% dan ekstrak cair > $20 \%$ [10]. Berdasarkan hasil perhitungan kadar air terhadap ekstrak kulit batang mangrove (Avicennia marina) didapatkan nilai sebesar 7\%. Sehingga dapat diketahui bahwa ekstrak kulit batang mangrove (Avicennia marina) cukup aman dari kontaminasi jamur selama penyimpanan.

\subsection{Uji Bebas Etanol Ekstrak Kulit Batang Mangrove (Avicennia marina)}

Berdasarkan hasil penelitian, didapatkan tidak timbulnya bau ester dari hasil reaksi esterifikasi yang dilakukan. Menunjukkan bahwa tidak terbentuknya senyawa aspirin.

\subsection{Skrining Fitokimia Ekstrak Kulit Batang Mangrove (Avicennia marina)}

Identifikasi kandungan senyawa aktif dalam ekstrak yang dilakukan dengan menggunakan uji tabung (melihat warna dan endapan). Hasil uji skrining fitokimia ekstrak kulit batang mangrove (Avicennia marina) yaitu uji alkaloid, terpenoid, tanin, saponin, menunjukan hasil positif (+), sedangkan uji flavonoid hasilnya (-) negatif.

\subsection{Evaluasi Karakteristik Fisik Krim}

\subsubsection{Uji Organoleptis}

Hasil uji pengamatan secara organoleptis menunjukkan bahwa krim ekstrak Kulit Batang Mangrove (Avicennia marina) dengan konsentrasi ekstrak 2,5\%, 5\%, 7,5\% serta minyak atsiri jeruk nipis (Citrus aurantifolia) $5 \%$, menghasilkan perbedaan warna pada krim yang terbentuk. Perbedaan warna disebabkan karena perbedaan konsentrasi ekstrak yang digunakan, semakin tinggi konsentrasi ekstrak yang ditambahkan, menghasilkan gradient warna krim yang lebih pekat. Konsistensi bentuk krim tidak mengalami perubahan setelah di simpan selama 2 minggu. Kesimpulannya, formulasi yang dihasilkan memiliki konsistensi 
warna yang baik, bau yang khas, dan konsistensi bentuk yang baik, karena ketiga formulasi krim tetap stabil.

\subsubsection{Uji Homogenitas Krim}

Hasil pengujian homogenitas menunjukkan bahwa krim ekstrak kulit batang mangrove (Avicennia marina) F1, F2 dan F3 menunjukan susunan yang homogen, ditandai dengan warna sediaan krim merata tidak terdapat partikel-partikel yang menggumpal. Uji homogenitas sediaan krim ekstrak kulit batang mangrove (Avicennia marina) menunjukkan bahwa krim tetap homogen dan tidak ada terjadinya pemisahan dari sediaan krim.

\subsubsection{Uji Daya Sebar}

Persyaratan daya sebar untuk sediaan topikal yaitu sekitar 5-7 $\mathrm{cm}$ atau 19,62-38,46 cm2. Kemampuan sebaran yang baik ketika diaplikasikan di kulit dapat membantu sediaan dalam meratakan zat aktif agar memaksimalkan efektivitasannya serta dapat diabsorpsi dengan cepat oleh kulit [11]. Hasil uji daya sebar menunjukan bahwa setiap formulasi memiliki daya sebar yang berbeda-beda yang disebabkan oleh pengaruh dari ekstrak. Sediaan yang memiliki daya sebar paling besar yaitu pada F1. Pada F1 dengan rata-rata daya sebar sebesar $5,45 \mathrm{~cm}$, sedangkan pada F2 memiliki rata-rata daya sebar sebesar $5,35 \mathrm{~cm}$, dan F3 sebesar 5,20 cm.

\subsubsection{Uji pH}

Hasil uji pH krim ekstrak kulit batang mangrove (Avicennia marina) ketiga formulasi yaitu F1, F2 dan F3 memiliki pH yang sama yaitu 6. Dari hasil tersebut dapat disimpulkan bahwa sediaan krim ekstrak kulit batang mangrove (Avicennia marina) memiliki nilai dengan rentang $\mathrm{pH}$ yang sesuai seperti pada literatur penelitian sebelumnya [5].

\subsubsection{Uji Daya Lekat}

Nilai standar uji daya lekat yaitu tidak boleh $<0,07$ menit atau $<4$ detik [9]. Hasil uji daya lekat pada formulasi 1 memiliki rata-rata yaitu 4,10 detik pada formulasi 2 memiliki ratarata 4,21 detik dan formulasi 3 memiliki rata-rata 5,13 detik dapat disimpulkan formulasi 1,2 dan 3 memenuhi standar karena $>4$ detik.

\subsubsection{Uji Viskositas}

Hasil uji viskositas menunjukan bahwa setiap formulasi sediaan krim ekstrak kulit batang mangrove (Avicennia marina) F1, F2 dan F3 memiliki viskositas yang berbeda. Selain itu penambahan propilenglikol pada formulasi dapat meningkatkan viskositas, karena propilenglikol mampu menarik air yang menyebabkan kulit terhidrasi dan menjadi lembab. Ketiga formulasi krim ekstrak kulit batang mangrove (Avicennia marina) memenuhi nilai strandar (cPs) yaitu $4000-40.000$, dari ketiga formulasi krim ekstrak kulit batang mangrove A. marina nilai setandar (cPs) paling tinggi pada sediaan F3 hal ini menunjukan bahwa penambahan konsentrasi ekstrak yang lebih besar mempengaruhi tingginya nilai viskositas.

\subsubsection{Uji Tipe Krim}

Hasil uji tipe krim pada sediaan krim ekstrak kulit batang mangrove (Avicennia marina) pada F1, F2 dan F3 menunjukan tipe krim yang sama yaitu krim tipe minyak dalam air $(\mathrm{M} / \mathrm{A})$.

\subsection{Uji Aktivitas Antibakteri Sediaan Krim Kombinasi Ekstrak Kulit Batang Mangrove (Avicennia marina) Dan Minyak Jeruk Nipis (Citrus aurantifolia)}

Hasil rata-rata diameter zona hambat dari ketiga formulasi berbeda yaitu F1 ( $27 \mathrm{~mm}$ ), F2 ( $29 \mathrm{~mm}$ ), F3 ( $34 \mathrm{~mm}$ ) dan kontrol positif ( 40,3 mm ). Hal ini dikarenakan pada ke 3 formulasi Sediaan Krim Ekstrak Kulit Batang Mangrove (Avicennia marina) memiliki konsentrasi jumlah ekstrak yang berbeda yaitu Pada F1 (2,5 \%), F2 (5\%), F3 (7,5\%). Sedangkan pada kontrol (-) tidak memiliki zona hambat karena hanya menggunakan basis krim dan tidak menggunakan ekstrak. Semuanya memiliki kategori zona hambat sangat kuat. Range dikatakan lemah jika diameter zona hambat $<5 \mathrm{~mm}$, dikatakan sedang yaitu 5-10 mm, kuat 10-20 mm dan dikatakan sangat kuat jika $>20 \mathrm{~mm}$ [10]. Berdasarkan hasil perbandingan besarnya zona hambat sediaan Krim Kombinasi Ekstrak Kulit Batang Mangrove (Avicennia marina) dan minyak atsiri Jeruk Nipis (Citrus aurantifolia) dengan penelitian sebelumnya, 
dapat disimpulkan bahwa penambahan minyak atsiri Jeruk Nipis (Citrus aurantifolia) kurang bekerja secara efektif dalam penghambatan Staphylococcus aureus ATCC 25923 [4]. Hal ini dikarenakan zona hambat yang di dihasilkan pada penelitian sebelumnya yaitu Formulasi Dan Uji Aktivitas Antibakteri Sediaan Krim Ekstrak Kulit Batang mangrove (Avicennia marina) Terhadap Pertumbuhan Staphylococcus aureus, zona hambat yang diperoleh $25 \mathrm{~mm}$ sudah dalam kategori sangat kuat, sedangkan pada Krim Kombinasi Ekstrak Kulit Batang Mangrove (Avicennia marina) dan minyak atsiri Jeruk Nipis (Citrus aurantifolia) diperoleh hasil $30 \mathrm{~mm}$, hal ini menandakan bahwa penambahan minyak atsiri Jeruk Nipis (Citrus aurantifolia) pada Krim Kombinasi Ekstrak Kulit Batang Mangrove (Avicennia marina) dan minyak atsiri Jeruk Nipis (Citrus aurantifolia) tidak ada peningkatan zona hambat yang signifikan karena hanya bertambah $5 \mathrm{~mm}$ saja.

\section{KESIMPULAN}

Ekstrak Kulit Batang mangrove (Avicennia marina) dan minyak atsiri Jeruk Nipis (Citrus aurantifolia) dapat diformulasikan menjadi krim kombinasi tipe M/A. Hasil semua evaluasi karteristik fisik krim memenuhi standar persyaratan. Pada uji organoleptis menujukan warna yang berbeda pada ketiga formulasi sedangkan untuk bau dan tekstur hasilnya sama, pada uji homogenitas semua formulasi menunjukan hasil homogen, pada uji $\mathrm{pH}$ dari ketiga formulasi menunjukan $\mathrm{pH}$ 6, pada uji viskositas formulasi terbaik ditunjukan pada F3, pada uji daya sebar formulasi terbaik ditunjukan pada F1, dan pada uji daya lekat formulasi terbaik ditunjukan pada F3.

Formulasi sediaan krim Ekstrak Kulit Batang mangrove (Avicennia marina) dan minyak atsiri Jeruk Nipis (Citrus aurantifolia) memiliki aktivitas antibakteri terhadap Staphylococcus aureus ATCC 25923. F1 dengan rata-rata zona hambat yaitu $27 \mathrm{~mm}$, pada F2 rata - rata zona hambat yaitu $29 \mathrm{~mm}, \mathrm{~F} 3$ rata-rata zona hambatnya yaitu $34 \mathrm{~mm}$, serta pada kontrol positif (Kloramfenikol 2\%) yaitu 40,3 mm, sedangkan pada kontrol negatif (basis krim) tidak memiliki zona hambat $(0 \mathrm{~mm})$. Jadi dari ketiga formulasi terbaik yang menghambat aktivitas antibakteri terhadap Staphylococcus aureus ATCC 25923 yaitu pada F3 yaitu zona hambatnya sebesar 34 $\mathrm{mm}$, karena adanya penambahan konsentrasi ekstrak paling besar yaitu 7,5\%.

\section{DAFTAR PUSTAKA}

[1] Paju N, Yamlean PFY, Kojong N, "Uji efektifitas Salep Ekstrak Daun Binahong (Anredera cordifolin Ten stein) Pada Kelinci Yang Terinfeksi Bakteri Staphylococcus aureus"; journal of FMIPA UNSRAT. Manado,2013, [Online]

[2] Kordi GH, "Ekosistem Mangrove: Potensi, Fungsi, dan Pengelolaan". Jakarta : Penerbit Rineka Cipta, 2012, [Online]

[3] Renaldi,dkk, "Bioaktivitas Senyawa Bioaktif Pada Mangrove Avicennia Marina Dan Bruguiera Gymnorrhiza Sebagai Antibakteri Yang Diambil Dari Pulau Payung Dan Tanjung Api-Api” Jurnal Universitas Sriwijaya, Indralaya, Indonesia, 2018, [Online]

[4] Widiasningrum, D, "Uji Daya Hambat Antibakteri Minyak Atsiri Dari Daun Jeruk Nipis (Citrus aurantifolia swingle) Terhadap Pertumbuhan Bakteri Staphylococcus aureus". Fakultas Farmasi, STIFAR, Semarang, 2004, [Online]

[5] Atmoko AD, Anom P, "Formulasi Bentuk Sediaan Krim Ekstrak Daun Sirih (Piper Betle Linn) Hasil Isolasi Metode Maserasi Etanol 90\%”, Indonesian Journal on Medical Science, Vol.1(2), 2014 , [Online]

[6] Marliana, S.D., Saleh, C, "Uji Fitokimia dan Aktivitas Antibakteri Ekstrak Kasar Etanol, Fraksi nHeksana, Etil asetat, dan Metanol dari Buah Labu Air (Lagenari Siceraria (Morliana)", Jurnal Kimia Mulawarman, 8(2): 39-63, 2011, [Online] 
[7] Sangi, M., M.R.J. Runtuwene., H.E.I. Simbala, dan V.M.A. Makang, "Analisis Fitokimia Tumbuhan Obat di Kabupaten Minahasa Utara", Chem. Prog., 1(1): 47-53, 2008, [Online]

[8] Agustia, Rahmatul Ashri (2019) Uji Aktivitas Tonikum Ekstrak dan Fraksi Rimpang Kencur (Kaempferia galanga L.) Pada Mencit Putih Jantan (Mus musculus). Skripsi, Universitas Setia Budi. Solo, 2019, [Online]

[9] Voigt, R. Buku Pelajaran Teknologi Farmasi Edisi Kelima, diterjemahkan oleh Drs. Soendani Noerono. 1994. Yogyakarta: Gadjah Mada University Press.

[10] Saraswati, A., "Efektivitas Ekstrak Daun Teh Hijau (Camellia sinensis) Dengan NaOCl 2,5\% Terhadap Bakteri Enterococcus faecalis Sebagai Alternatif Lautan Irigasi Saluran Akar", Skripsi., Fakultas Kedokteran Ggi Universitas Hasanudin., Makassar 2015 , [Online]

[11] Ulaen, Selfie P.J., Banne, Suatan, Y., dan Ririn A, "Pembuatan Salep Anti Jerawat dari Ekstrak Rimpang Temulawak (Curcuma xanthorrhiza Roxb.)", Jurnal Ilmiah Farmasi, 3(2): 45-49, 2012 , [Online] 